\title{
Supply chain analysis of hedonic shopping value on behavioral intention creation of multinational footwear company
}

\section{Lili Adi Wibowo ${ }^{a^{*}}$, Bambang Widjajanta ${ }^{a}$, Anbar Fadillah ${ }^{a}$, Ari Riswantob ${ }^{b}$ Vika Apriantic, Yani Restiani Widjaja ${ }^{d}$, Andi Primafira Bumandava Eka ${ }^{e}$, Hernandi Sujono ${ }^{f}$ and Mochamad Vrans Romi ${ }^{\mathbf{f}}$}

${ }^{a}$ Universitas Pendidikan Indonesia

${ }^{b}$ Sekolah Tinggi Keguruan \& Ilmu Pendidikan PGRI Sukabumi, Indonesia

${ }^{c}$ Universitas Informatika \& Bisnis Indonesia, Indonesia

${ }^{d}$ Universitas Adirajasa Reswara Sanjaya, Indonesia

e STIE Manajemen Bisnis Indonesia, Indonesia, Indonesia

${ }^{f}$ Universitas Jendral Ahmad Yani, Indonesia

\section{H R O N I C L E}

\section{Article history:}

Received January 2, 2020

Received in revised format June

8,2020

Accepted July 172020

Available online

July 172020

Keywords:

Behavioral intention

Hedonic Shopping value

Supply chain management

Multinational company

product

\section{A B S T R A C T}

\begin{abstract}
This study aims to obtain an overview of hedonic shopping value, a description of behavioral intention, and the magnitude of the influence of hedonic shopping value on behavioral intention with supply chain analysis. The design of this study was cross sectional using a descriptive and verification type approach; namely by exposing the related variables to test the relationship or influence which then formed conclusions. The object of research that is the dependent variable is behavioral intention and hedonic shopping value. The population in this study were members of the Adidas Community 3Foil.id in Indonesia. The method used is probability sampling with a sample size of 218 respondents with characteristics that respondents must be Members of Adidas Community 3Foil.id, at least 18 years old, and have shopped at least more than once on Adidas products and intend to buy back. The data analysis technique used is structural equation modeling (SEM). The findings of this study show that the existence of hedonic shopping value and behavioral intention is in a fairly good category. Moreover, hedonic shopping value has a significant influence on behavioral intention. The findings managerially imply that companies stimulate the hedonic motivation of 3Foil.id Adidas Community Members in Indonesia, because hedonic shopping values affect customer satisfaction and consumer behavioral intention in supply chain perspective, especially for multinational companies.
\end{abstract}

(C) 2020 by the authors; license Growing Science, Canada.

\section{Introduction}

Shopping tourism is one of the tourism industries that is experiencing significant growth in the world (Astari et al., 2017). Shopping has become a thing that is done by tourists every time they travel both the archipelago and foreign tourists. In a supply chain analysis, it is incomplete if tourists on a trip do not spend time to shop and multinational products were available to be bought. Foreign and domestic companies in Indonesia compete to meet the needs, desires, and understand consumer behavior (Aisyah et al., 2019). The increasing growth of the upper class, there will be opportunities to meet the lifestyle that needs to be fulfilled by the company owner. A person's lifestyle in the world expressed in him is influenced by his activities, interests and thoughts (Kotler \& Gertner, 2002). Companies must know and understand the behavior of their target markets (Schiffman et al., 2009). At present most consumers in Indonesia are more leisure oriented when shopping. For example, shopping for Adidas products is one indicator that Adidas products are supported by its integrated

* Corresponding author

E-mail address: lawibowo.upi@gmail.com (L. A. Wibowo)

C 2020 by the authors; licensee Growing Science. doi: 10.5267/j.uscm.2020.7.005 
supply chain management and differentiation are needed by the community (Wijatmoko, 2014; Hofmann \& Knébel, 2016; Mefford, 2011). Shoe companies in Indonesia are considered to be experiencing significant development and has connected with global supply chain manufacturing (Murdoyo, 2014; Er \& MacCarthy, 2002). Increasing business competition in the field of shoes makes many choices for customers to be able to choose products that match their expectations. Companies must pay more attention to the quality and price of their products in order to attract consumers to buy back in the future. Moreover, there are a number of shoe products in Indonesia that present towards the upper class or premium, one of which is Adidas brand shoes. As a multinational company with global supply chain management, Adidas offers premium, quality products that make a person pay more to get it. The advantages and disadvantages of Adidas shoes can affect consumers' motivation in shopping with its superior advantages in product quality and global supply chain (Tate et al., 2010; Cordon et al., 2013; Taylor, 2009). In many parts of world, Adidas is capable of retaining its loyal consumers by supply chain segmentation and integration (Roscoe \& Baker, 2014; Du, 2007). Members of the Adidas Community 3Foil.id are one of the adidas shoe lovers communities in Indonesia, whose many members have a high level of hedonism. Other research shows that with the motivation of hedonic shopping value, a person will behave again in the future to conduct behavioral intention which means to influence consumers to be loyal and want to be involved in business development and progress (Khuana, 2016). Based on the background that has been stated, the problems that arise are:

RQ1. What is the description of behavioral intention that will be measured through indicators of loyalty, recommendations and premium prices for 3 Foil.id Adidas Community Members in Indonesia?

$R Q 2$. What is the description of hedonic shopping value that will be measured through indicators of adventure shopping, social shopping, gratification shopping, idea shopping, role shopping, and value shopping for 3Foil.id Adidas Community Members in Indonesia?

RQ3. Is there a hedonic shopping value effect on behavioral intention on the 3Foil.id Adidas Community Members in Indonesia?

\section{Literature Review}

The growth of the world footwear industry is largely contributed by sport-based tourism, and use by loyal consumers. Supported by a globally integrated supply chain management, this industry can directly target consumers by offering shoes at premium prices (Majeed \& Rupasinghe, 2017; Soroor et al., 2009; Bruce et al., 2004; Tantra, 2018). Directly, these various offers will influence consumer spending patterns and their shopping acivities. Shopping activities initially carried out by consumers are motivated by rational motives, which are related to the benefits provided by the product. Experience became the main thing sought by consumers in early 2010 rather than the products and services themselves (Koeswandi et al., 2017). Another value that affects shopping activities carried out by consumers is the value that is emotional or known as hedonic shopping value. Consumers will also pay attention to aspects of enjoyment and pleasure that can be obtained in addition to the benefits of the product that will be enjoyed in the shopping activities they do. Hence, hedonic values are defined as motivations that are triggered through the five senses, imagination and emotions, where these three bases are a reference for classification of hedonic motivation to make purchases based on experience (Arnold \& Reynolds, 2003). The customer experience is reflected in the ability of the company's service providers to keep customers loyal, pay premium prices, and spread positive words of mouth. Companies need to pay attention to behavioral intention as one of the important aspects in facing competition. The high satisfaction of customers who feel excitement can have an impact for a repeat purchase and are willing to recommend it to others, and this is also relevant to the shoe industry (Gupta et al., 2007). Behavioral intention has an important role in an effort to show consumer behavior about experience to maintain customer relationships in the long run (Solomon et al., 2007). Behavioral intention affects several components, namely; consumer attitudes toward the behaviors they exhibit, the social pressures they receive, and control over the behaviors they receive (Kanuk and Schiffman, 2012; Khuana, 2016; Pourkhani et al., 2019).

The low behavioral intention in the long run can affect customer loyalty, decrease company revenue, and threat the company's presence in the future (Kim et al., 2013; Rahi et al., 2018). Research that has been done previously shows that there are several ways that can be done to increase low behavioral intention by forming or increasing consumer preferences for products. In addition, it can also be done by building hedonic shopping values that are in accordance with the emotions, satisfaction, and enjoyment of consumers (Kristina et al., 2017). The problem of low behavioral intentions must be corrected quickly, because if consumers are less willing to recommend a product to others, that means competing shoe products take other ways to attract consumers (Wibowo et al., 2016). Behavioral intention is able to describe the extent to which a person

formulates a conscious plan to do or not do some behavior in the future (Foroughi et al., 2016). There are two groups of behavioral intention, namely positive and negative, positive conditions generally consist of the intention to recommend, the intention to reuse and accept to pay a higher price (Balikçioglu, 2015). Negative conditions include complaints to friends or external institutions, and turn to competitors (Foroughi et al., 2016; Handayani et al., 2018).

\section{Research Methods}

This research was conducted to find a picture of the hedonic shopping value of behavioral intention. The independent variables in this study are hedonic shopping value with adventure shopping, social shopping, gratification shopping, idea 
shopping, role shopping, and value shopping. Meanwhile, the dependent variable is behavioral intention with dimensions of loyalty, recommendation, and premium price. Based on the variables studied, the type of this research is descriptive and verification research with explanatory survey method. The purpose of this descriptive study is to find out the overall picture of the hedonic shopping value of behavioral intention. Verification research aims to test the truth of the relationship between hedonic shopping values and behavioral intention. Population relates to the whole group of people, events, symptom objects, phenomena, or events that are the center of attention of researchers to be investigated (Hermawan, 2006: 143). The population selected in this study is the Indonesian people who belong to the 3Foil.id Adidas shoe lovers community. This study used a sample of 218 respondents, based on consideration of the level of confidence of 0.95 with $\alpha 0.05$ and errors that might occur no more than $10 \%$. Sources of data used are secondary data and primary data. The primary data source in this study was obtained from a questionnaire distributed to a number of respondents in accordance with the targets considered to be representative of the entire population of the research data, namely through a survey of 3Foil.id Adidas Community Members. Data collection techniques used were questionnaires, literature studies, and observations. Data analysis activities in this study were carried out through several stages ranging from compiling data, selecting data, tabulating data, analyzing data and testing. Hypothesis testing in this study was conducted using structural equation modeling (SEM) analysis techniques. Data processing using AMOS 19.0 for Windows and SPSS 24.0 for Windows.

\section{Results}

\subsection{Assumption of Structural Equation Modeling}

First, the sample size provides the basis for estimating sampling errors. The sample in this study was set with $\propto=5 \%$ or 0.05 obtained a minimum sample size (n) of 218 respondents, so this study uses the Maximum Likelihood estimation of non-formal data. Second, AMOS 19.0 output results indicate that the value of the critical ratio skewness value shows that the data set is normally distributed because each variable's critical ratio value is between -2.58 to 2.58 . Meanwhile, the multivariate critical ratio value of $-1,163$ indicates that this study has multivariate normally distributed data. It can be seen in Table 1 of data normality test results.

Table 1

Data Normality Test Results

\begin{tabular}{lllllll}
\hline Variable & min & max & skew & c.r. & kurtosis & c.r. \\
\hline Pre & 14.000 & 28.000 & -.456 & -2.763 & -.431 & -1.305 \\
Rec & 9.000 & 21.000 & -.422 & -2.557 & -.529 & -1.603 \\
Loy & 17.000 & 35.000 & -.201 & -1.219 & -.453 & -1.370 \\
Adv & 10.000 & 21.000 & -.295 & -1.785 & -.807 & -2.444 \\
Soc & 10.000 & 21.000 & -.374 & -2.267 & -.439 & -1.329 \\
Gra & 10.000 & 21.000 & -.384 & -2.324 & -.565 & -1.710 \\
Ide & 10.000 & 21.000 & -.290 & -1.757 & -.902 & -2.731 \\
Rol & 10.000 & 21.000 & -.179 & -1.086 & -.564 & -1.708 \\
Val & 12.000 & 21.000 & -.104 & -.629 & -.446 & -1.349 \\
\hline Multivariate & \multicolumn{7}{c}{-2.207} & & & -1.163 \\
\hline
\end{tabular}

Third, outlier data test results showed the farthest distance from the d-square mahalanobis value is 22.209 and the closest distance is 8.856 . The $\mathrm{p} 1$ and $\mathrm{p} 2$ values of the data with the farthest mahalanobis value are 0.020 and 0.988 respectively where one of the $\mathrm{p} 1$ and $\mathrm{p} 2$ values means $>0.05$ so it can be said that there is no outlier data and no need to be discarded (Table 2).

Table 2

Data Outliers Testing Results

Mahalanobis Distance (d2)

Assumption

\begin{tabular}{cccc} 
& Max. & Min. & $\chi \mathbf{2}$ \\
\hline Outliers & 19.693 & 9.032 & 38.88514 \\
\hline
\end{tabular}

Source: Data Processing Results, 2019

Multicollinearity: the output results give the determinant value of the sample covariance matrix $=2229995,71$. This value is far from zero so it can be interpreted that there is no multicollinearity and singularity in the analyzed data

\subsection{Structural Equation Modeling Testing}

After the model is made, then the data that has been through the basic assumption testing stage can be added to the research model for the next SEM testing phase. The data added consisted of 218 samples with 30 items in question, 18 items for hedonic shopping value variable questions and 12 items for behavioral intention variable questions. 


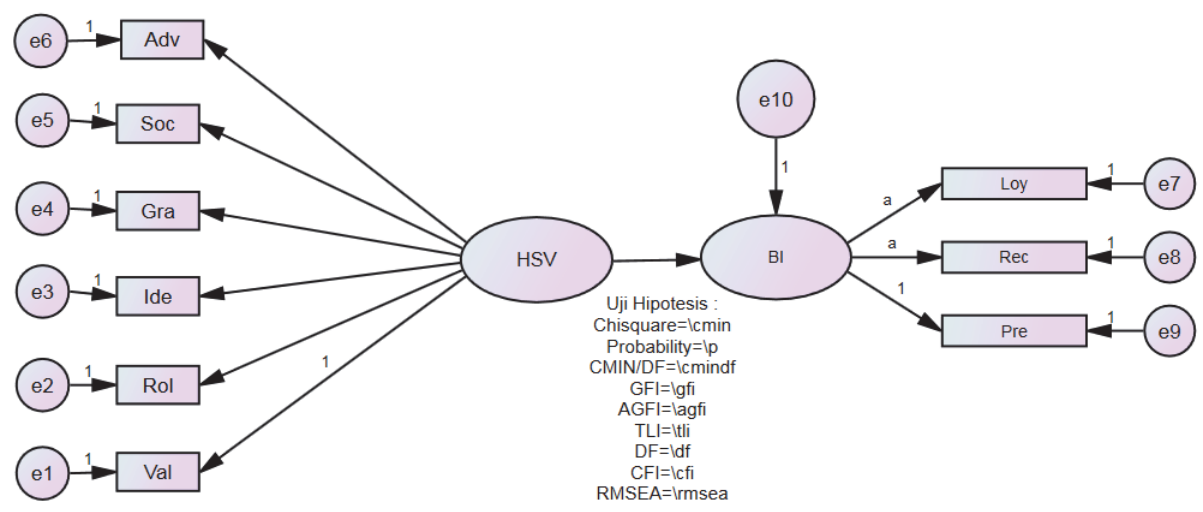

Fig. 1. Model Specifications

The results of data processing is based on using AMOS software version 19 for windows, in this study the value of degree of freedom (DF) obtained is $45-19=26$. This figure shows a positive number so that it can be said that identification in this research model is over identified which allows estimation and assessment of the model to be done further. Indicators and constructs that form each other in this research model can be said to be valid, because it shows the results of loading factors with a value $>0.5$. The highest factor loading factor is hedonic shopping value in forming behavioral intention with a value of 0.347 , the lowest result is shown by hedonic shopping value in forming the dimension of shopping value with a value of 0.511 . Table 3 shows the measurement model estimation testing results.

\section{Table 3}

Measurement Model Estimation Testing Results

\begin{tabular}{ll}
\hline Model & Estimate \\
\hline BI $\leftarrow$ HSV & .347 \\
Val $\leftarrow$ HSV & .625 \\
Rol $\leftarrow$ HSV & .628 \\
Ide $\leftarrow$ HSV & .692 \\
Gra $\leftarrow$ HSV & .737 \\
Soc $\leftarrow$ HSV & .755 \\
Adv $\leftarrow$ HSV & .708 \\
Loy $\leftarrow$ BI & .815 \\
Rec $\leftarrow$ BI & .788 \\
Pre $\leftarrow$ BI & .781 \\
\hline Note: BI= behavioral intention; HSV= hedonic shopping value; Val= value shopping; Rol= role shopping; ide= idea shopping; Gra= gratification &
\end{tabular}

Based on the measurement model estimation testing that shows the results of all dimensions and valid constructs ( $>0.5)$, the test can be carried out to the next stage, namely structural model testing through testing fit.

\subsection{Structural Model Match Test}

Structural model analysis is related to the evaluation of parameters that show causal relationships or the effect of one latent variable on other latent variables. The structure of the hedonic shopping value model to behavioral intention after a goodness of fit test is seen in Fig. 2 presenting the structural model of the hedonic shopping value on behavioral intention.

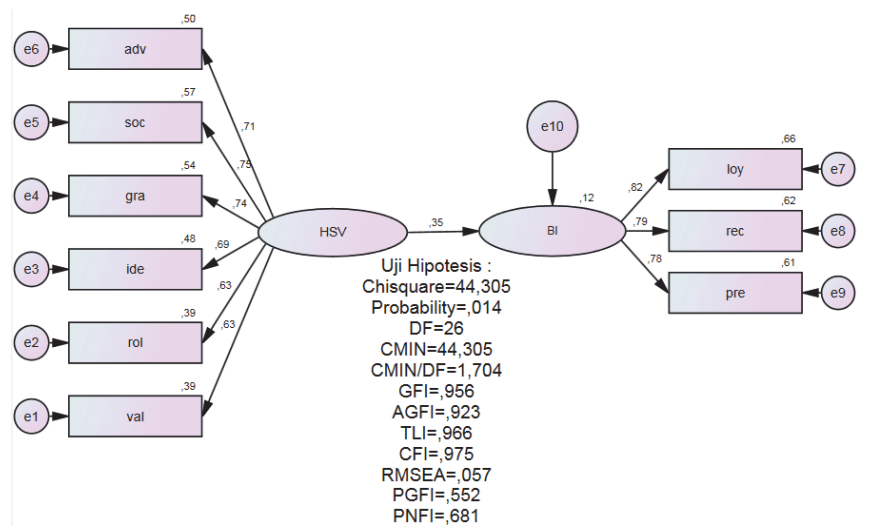

Fig. 2. Structural Model of Hedonic Shopping Value on Behavioral Intention 
SEM analysis shows the value obtained from the influence of hedonic shopping value on behavioral intention is 0.35 . Table 4 shows the results of estimated hedonic shopping value model parameters for behavioral intention.

Table 4

Estimation Results of the Hedonic Shopping Value Model Parameters for Behavioral Intention

\begin{tabular}{|c|c|c|c|c|c|}
\hline \multirow{2}{*}{ Model } & \multicolumn{2}{|c|}{ Estimate * } & \multirow{2}{*}{ SE } & \multirow{2}{*}{ C.R } & \multirow[b]{2}{*}{$\mathrm{P}$} \\
\hline & RW & SRW & & & \\
\hline $\mathrm{HSV} \leftarrow \mathrm{BE}$ & .923 & .347 & .226 & 4.088 & $* * *$ \\
\hline
\end{tabular}

The results of the significance test of the estimated path coefficients in the model after trimming are all significant at the $5 \%$ error rate or the $\mathrm{p}$-value value $<0.05$.

\subsection{Overall Model Fit}

The overall model fit test is carried out to evaluate in general the degree of compatibility or goodness of fit. In the Goodness of Fit test, the assessment criteria can be carried out according to the opinions of various experts. The Goodness of Fit Test Results show that although not all Goodness of Fit measures are in accordance with the recommendations and greater than the cut-off value, it can still be concluded that the overall model is fit because RMSEA value of $0.057 \leq 0.08$ (good fit), AGFI value $0.923 \geq 0.90$ (good fit), TLI value $0.966 \geq 0.90$ (good fit). In the goodness of fit test of this research model, there is a criterion value that has fulfilled the requirements by having a good fit value. So that it can be said that this model is declared marginally feasible to be used as a tool in confirming a theory that has been built based on existing observational data or it can be said that this model is fit or acceptable (Table 5).

Table 5

Goodness of Fit Test Results

\begin{tabular}{|c|c|c|c|c|}
\hline \multirow{2}{*}{ No } & Goodness of Fit Measures & Cut-off value & \multirow{2}{*}{ Results } & \multirow{2}{*}{ Model Evaluation } \\
\hline & Absolute Fit Measures & & & \\
\hline 1 & $\begin{array}{l}\text { Statistic Chi-square }\left(\mathrm{X}^{2}\right)(\mathrm{df}= \\
43)\end{array}$ & $\chi^{2}$ hit $<\chi^{2}$ Table & 44.305 & Good Fit \\
\hline 2 & Goodness of Fit Index (GFI) & $\begin{array}{l}\text { GFI } \geq 0.90 \text { good fit, } 0.80 \leq \mathrm{GFI}< \\
0.90 \text { marginal fit }\end{array}$ & 0.956 & Good Fit \\
\hline 3 & $\begin{array}{l}\text { Root Mean Square Error of } \\
\text { Approximation (RMSEA) }\end{array}$ & $\leq 0.08$ & 0.057 & Good Fit \\
\hline 4 & Trucker-Lewis Index (TLI) & $\begin{array}{l}\mathrm{TLI} \geq 0.90 \text { good fit, } 0.80 \leq \mathrm{TLI}< \\
0.90 \text { marginal fit }\end{array}$ & 0.966 & Good Fit \\
\hline 5 & $\begin{array}{l}\text { Adjusted Goodness of Fit } \\
\text { Indices (AGFI) }\end{array}$ & $\geq 0.90$ & 0.923 & Good Fit \\
\hline 6 & Comparative Fit Index (CFI) & $\begin{array}{l}\mathrm{CFI} \geq 0.90 \text { good fit, } 0.80 \leq \mathrm{CFI}< \\
0.90 \text { marginal fit }\end{array}$ & 0.975 & Good Fit \\
\hline 7 & $\begin{array}{l}\text { Parsimonious Goodness of fit } \\
\text { Index (PGFI) }\end{array}$ & $\mathrm{PGFI}<\mathrm{GFI}$ & 0.552 & Good Fit \\
\hline 8 & $\begin{array}{l}\text { Parsimonious Normed Fit Index } \\
\text { (PNFI) }\end{array}$ & $\begin{array}{l}\text { The higher the better, compared to } \\
\text { alternative models }\end{array}$ & 0.681 & Good Fit \\
\hline
\end{tabular}

\subsection{Hypothesis testing}

The influence between variables is said to be significant if the value of T-statistics is greater than 1.96. Table 6 shows a significant influence between hedonic shopping value variables on behavioral intention.

Table 6

Estimation Results of the Hedonic Shopping Value Model Parameters for Behavioral Intention

\begin{tabular}{|c|c|c|c|c|c|c|}
\hline \multirow{2}{*}{ Model } & \multicolumn{2}{|c|}{ Estimate } & \multirow{2}{*}{ S.E. } & \multirow{2}{*}{ C.R. } & \multirow{2}{*}{$\mathrm{P}$} & \multirow{2}{*}{$\mathrm{R}^{2}$} \\
\hline & RW & SRW & & & & \\
\hline $\mathrm{BI} \leftarrow \mathrm{HSV}$ & .924 & .348 & .226 & 4.084 & $* * *$ & .121 \\
\hline
\end{tabular}

Estimation results show that the magnitude of the effect of hedonic shopping value on behavioral intention is positive at 0.349 seen from the output total effect. With this value it can be said that there is a significant positive effect between hedonic shopping value on behavioral intention of 0.349 or $35 \%$. Processing on IBM SPSS AMOS data output version 22.0 for Windows there are several matrices that show the relationship between the factors forming a latent variable and its relationship with factors on other latent variables. Table 7 showed correlation matrix of all items. It presents an estimate or estimate of the population correlation matrix of all variables contained in the research model (observed and unobserved) with the standard loading factor value under the hypothesis that the research model is correct. 
Table 7

Correlation Matrix for all variables

\begin{tabular}{lc}
\hline \multicolumn{1}{c}{ Dimension Model } & Correlation \\
\hline Premium Price formed Adventure Shopping & 0.711 \\
Recommendations are formed by Adventure Shopping & 0.248 \\
Loyalty is formed by Adventure Shopping & 0.194 \\
Premium Price is formed by Social Shopping & 0.755 \\
Recommendations are formed by Social Shopping & 0.263 \\
Loyalty is formed by Adventure Shopping & 0.206 \\
Premium Price is formed by Gratification Shopping & 0.743 \\
Recommendations are formed by Gratification Shopping & 0.258 \\
Loyalty is formed by Gratification Shopping & 0.203 \\
Premium Price is formed by Idea Shopping & 0.695 \\
Recommendations are formed by Idea Shopping & 0.242 \\
Loyalty is formed by Idea Shopping & 0.190 \\
Premium Price is formed by Role Shopping & 0.635 \\
Recommendations are formed by Role Shopping & 0.221 \\
Loyalty is formed by Role Shopping & 0.173 \\
Premium Price is formed by Value Shopping & 0.625 \\
Recommendations are formed by Value Shopping & 0.217 \\
Loyalty is formed by Value Shopping & 0.171 \\
\hline
\end{tabular}

Based on Table 7, it can be seen that the value of the correlation or loading factor dimensions of the hedonic shopping value that most form the behavioral intention is the dimension of social shopping that correlates with the dimensions of the premium price of 0.755 or $75.5 \%$, while the most small obtained by the dimension of shopping value that correlates with the dimension of loyalty of 0.171 or $17.1 \%$.

\section{Discussion}

In this study the behavioral intention variable consists of three dimensions with 12 indicators. This study found that the sequence of behavioral intention dimensions of the highest value was loyalty, premium price and recommendation. When viewed based on the overall dimensions of behavioral intention, the first dimension of loyalty that gets the highest achievement with a percentage of $80.4 \%$ of the score obtained is 6189 compared to the ideal score of 7700 , meaning that most of the members of the Adidas 3Foil.id community in Indonesia can be said consumers are willing to go back to buying Adidas products quite high. The premium price dimension achieved the lowest achievement with a percentage of $77.7 \%$ with an ideal score of 6160 and obtained a score of 4789, it can be said that members of the Adidas 3Foil.id community in Indonesia are still quite low compared to the dimensions of loyalty and recommendation. This illustrates that the premium price dimension is one factor that must be considered by companies and consumers. The results show that the loyalty dimension has an important role in creating behavioral intention. This illustrates that the loyalty dimension is a factor of concern to consumers because loyalty is a very strong consumer commitment to buy back or replace products consistently in the future, despite the situational influence and marketing efforts that have the potential to cause switching behavior. Moreover, in this study the hedonic shopping value variable consists of six dimensions with 18 indicators. This study found that the dimensions of the hedonic shopping value sequence of the highest value are adventure shopping, value shopping, social shopping, grafitication shopping, role shopping and idea shopping. The dimension of adventure shopping gets the highest percentage of achievement with a score of 3787 or $82.7 \%$ of the ideal score of 4578 meaning it can be said that members of the Adidas 3Foil.id community in Indonesia almost all have an adventure spirit in shopping. Most of the members of the 3Foil.id Adidas community shop because there is something that can arouse the consumer's own shopping excitement, one of which is through the shopping experience so that consumers feel they have their own world when they talk about Adidas shoes through their friends. The dimension of idea shopping has the lowest achievement of all dimensions with a percentage of $76.8 \%$ of the total score of 3517 compared to the ideal score of 4578 . In these conditions it also shows that the majority of consumers also believe that doing shopping activities aims to follow the trend of Adidas shoes exist in the community. Members of the Adidas Community 3Foil.id in Indonesia mostly follow the new fashion trends to see new products or things. Usually consumers see something new from advertisements or promotions offered through mass media so as to make members of the Adidas community feel compelled to follow the trend to be recognized. The results showed that the dimension of adventure shopping has an important role in creating hedonic shopping value. It also can encourage consumers to assume that shopping activities as an adventure that reinforces the consumer's hedonic values associated with feelings, fantasies, pleasures, and senses, where the experience affects one's emotions. Lastly, results note that the significant influence is the T-statistics test results with a value of 4.003, which is above 1.96. So it can be said that the hedonic shopping value influences behavioral intention in 3Foil.id Adidas Community Members in Indonesia. Members of the Adidas Community 3Foil.id in Indonesia certainly have an assessment of their motivation to buy Adidas shoes, not just from wanting to shop but taking into consideration the social status they receive, gifts to themselves or to their closest relatives and also because they can only enjoy themselves. as an experience wearing shoes at a premium price. With this motivation, 
a person will behave again in the future to conduct behavioral intention in the sense of influencing consumers to be loyal and want to be involved in business development and progress.

\section{Conclusion}

The findings from analysis of hedonic shopping values of Adidas as a multinational company with superior global supply chain showed that hedonic shopping value was described from dimensions consisting of adventure shopping, social shopping, gratification shopping, idea shopping, role shopping and value shopping, which are in quite good categories. This shows that the hedonic value felt by members of the Adidas 3Foil.id community in Indonesia can be said to be quite good overall. The dimension that gets the highest response is the adventure shopping dimension, while the dimension with the lowest response acquisition is the idea shopping dimension. Behavioral intention among members of the Adidas 3Foil.id community in Indonesia can be seen from its dimensions consisting of loyalty, recommendations and premium prices which are in quite good categories. This shows that the behavioral intention condition of Adidas has shown quite good performance. The dimension that gets the highest response is the loyalty dimension and the dimension with the lowest response acquisition is the premium price. Moreover, hedonic shopping value statistically has a positive and significant influence on behavioral intention among members of the 3Foil.id Adidas community in Indonesia. This is indicated by the large value of critical ratio that is far greater than $t$ arithmetic which causes Ho to be rejected. This means that hedonic shopping value is a significant explanation of behavioral intention. This shows that the better the hedonic value is given, the more it creates an intention to behave positively. The findings managerially imply that companies must stimulate the hedonic motivation of 3Foil.id Adidas Community Members in Indonesia, because hedonic shopping values affect customer satisfaction and consumer behavioral intention. The higher the consumer's hedonic shopping value, the higher the level of positive behavioral intention given by 3Foil.id Adidas Community Members in Indonesia. The implementation that can be done by companies is by holding interesting promos that are often published on social media, in collaboration with influencers throughout Indonesia, but also by increasing the trend of events that are rife in the world of Indonesian Sports such as Marathon, Event Running with Adidas, or Snickers society with frequent promos or events that are in line with the premium image of Adidas, consumers will often shop and can form the hedonic shopping value sought by consumers.

\section{References}

Aisyah, A., Wibowo, L. A., \& Widjajanta, B. (2019). Promotion Mix Solusi Untuk Meningkatkan Keputusan Pembelian. Strategic: Jurnal Pendidikan Manajemen Bisnis, 19(1), 1-6.

Astari, B., Wibowo, L. A., \& Ridwanudin, O. Pengaruh Store Attribute Terhadap Loyalitas Wisatawan Dikontrol Oleh Motivasi Berbelanja. Jurnal Ilmu Manajemen \& Bisnis, 7(1), 27-32.

Bruce, M., Daly, L., \& Towers, N. (2004). Lean or agile: a solution for supply chain management in the textiles and clothing industry?. International Journal of Operations \& Production Management, 24(2), 151-170.

Cordon, C., Hald, K. S., \& Seifert, R. W. (2013). Strategic supply chain management. Routledge.

Du, L. (2007). Acquiring competitive advantage in industry through supply chain integration: a case study of Yue Yuen Industrial Holdings Ltd. Journal of Enterprise Information Management, 20(5), 527-543.

Durna, U., Dedeoglu, B. B., \& Balikçioglu, S. (2015). The role of servicescape and image perceptions of customers on behavioral intentions in the hotel industry. International Journal of Contemporary Hospitality Management, 27(7), 1728-1748.

Er, M., \& MacCarthy, B. (2002, September). Configuration of international supply networks and their operational implications: evidences from manufacturing companies in Indonesia. In Proceedings of the 7th Cambridge International Manufacturing Symposium, Cambridge (pp. 12-13).

Foroughi, B., Nikbin, D., Hyun, S. S., \& Iranmanesh, M. (2016). Impact of core product quality on sport fans' emotions and behavioral intentions. International Journal of Sports Marketing and Sponsorship, 17(2), 110-129.

Handayani, W., Anshori, M., Usman, I., \& Mudjanarko, S. (2018). Why are you happy with impulse buying? Evidence from Indonesia. Management Science Letters, 8(5), 283-292.

Hermawan, A. (2006) Penelitian Bisnis: Paradigma Kuantitatif. Jakarta: Grasindo.

Hofmann, E., \& Knébel, S. (2016). Supply chain differentiation: background, concept and examples. Journal of Service Science and Management (JSSM), 9(2), 160-174.

Khuana, K. (2016). Pengaruh Hedonic Value Terhadap Behavioral Intention Dengan Customer Satisfaction Sebagai Variabel Intervening (Studi Kasus Pada: 1903-Heritage Dining). Jurnal Strategi Pemasaran, 3(2), 9.

Koeswandi, T., Rahayu, A. And Wibowo, L. A. (2017). Pengaruh Atmosfer Terhadap Costumer' Impression Dan Dampaknya Pada Minat Beli Ulang ( Survei Pengunjung Chingu Korean Fan Café Di Kota Bandung ). Jurnal Ilmu Manajemen \& Bisnis, 8(2), 33-41.

Kristina, R. (2017). Analisis Pengaruh Brand Knowledge Dan Customer Preference Terhadap Behavior Intention Pada Fast Fashion Di Surabaya Dengan Brand Cause Fit Sebagai Variabel Mediasi. Jurnal Strategi Pemasaran, 4(2), 1-10.

Majeed, A. A., \& Rupasinghe, T. D. (2017). Internet of things (IoT) embedded future supply chains for industry 4.0: An assessment from an ERP-based fashion apparel and footwear industry. International Journal of Supply Chain Management, 6(1), 25-40.

Mefford, R. N. (2011). The economic value of a sustainable supply chain. Business and Society Review, 116(1), $109-143$. 
Murdoyo, T. (2014). Analisis Faktor-Faktor Yang Mempengaruhi Konsumen Dalam Pengambilan Keputusan Pembelian Produk Sepatu Futsal Merk Adidas Pada Pelanggan Lapangan Futsal. Journal Of Business Management 1(1), 1-104.

Pourkhani, A., Abdipour, K., Baher, B., \& Moslehpour, M. (2019). The impact of social media in business growth and performance: A scientometrics analysis. International Journal of Data and Network Science, 3(3), 223-244.

Rahi, S., Ghani, M., \& Ngah, A. (2018). A structural equation model for evaluating user's intention to adopt internet banking and intention to recommend technology. Accounting, 4(4), 139-152.

Roscoe, S., \& Baker, P. (2014). Supply chain segmentation in the sporting goods industry. International Journal of Logistics Research and Applications, 17(2), 136-155.

Soroor, J., Tarokh, M. J., \& Shemshadi, A. (2009). Theoretical and practical study of supply chain coordination. Journal of Business \& Industrial Marketing, 24(2), 131-142.

Tantra, A.R. (2018). Factors Affecting Intellectual Capital Disclosure and Company Value. Arthatama: Journal of Business Management and Accounting 2(1), 1-13.

Tate, W. L., Ellram, L. M., \& Kirchoff, J. F. (2010). Corporate social responsibility reports: a thematic analysis related to supply chain management. Journal of Supply Chain Management, 46(1), 19-44.

Taylor, D. H. (2009). An application of value stream management to the improvement of a global supply chain: a case study in the footwear industry. International Journal of Logistics: Research and Applications, 12(1), 45-62.

Wibowo, L. A., Fitriani, F. N., \& Ridwanudin, O. (2016, August). The Influence of Perceived Value Against Behavioral Intentions. In 2016 Global Conference on Business, Management and Entrepreneurship. Atlantis Press.

Wijatmoko, A. C (2014). Pengaruh Sensitivitas Harga Terhadap Nilai Hedonik Dan Nilai Utilitarian Dalam Membeli Sepatu Futsal. Journal Customer Behavoiur, 1(1).

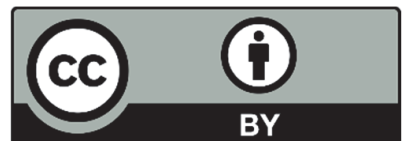

(C) 2020 by the authors; licensee Growing Science, Canada. This is an open access article distributed under the terms and conditions of the Creative Commons Attribution (CC-BY) license (http://creativecommons.org/licenses/by/4.0/). 